\title{
Community structure of estuarine meiobenthos
}

\author{
R. M. Warwick and J. M. Gee
}

NERC Institute for Marine Environmental Research, Prospect Place, The Hoe, Plymouth PL1 3DH, United Kingdom

\begin{abstract}
Meiofaunal samples were collected from intertidal mudflats in the lower, middle and upper reaches of the Tamar estuary, South West England in April and October, 1982. Species abundance and biomass patterns of nematodes and copepods did not follow the expected trends in relation to salinity: the lowest species diversity (below neutral model predictions), the steepest ranked species abundance curves and the greatest departure from the theoretical lognormal distribution of numbers and biomass of individuals among species were found at the middle rather than the upper site. Huston's (1979) dynamic equilibrium hypothesis is invoked to explain these phenomena, but the hypothesis remains to be tested. Intense macrofaunal predation and disturbance, together with more pronounced environmental fluctuations, may eliminate competitive exclusion at the upper site resulting in a relatively high species diversity. The absence of such population reduction mechanisms at the middle site results in competitive exclusion and lowered diversity. The major nematode species at the upper site have certain opportunistic characteristics, and at the middle site conservative characteristics, which support the contention that these are respectively successional and climax communities. The lower site may represent an intermediate successional stage with the highest diversity. The apparent correlation between the abundances of 3 copepod and 1 nematode species with changes in salinity at the middle and upper sites between April and October is thought to result from passive suspension and transport of these species upstream during the summer: there is a distinct fine-scale vertical stratification of species in the sediment at the middle site, with the species in question having an extreme surficial distribution.
\end{abstract}

\section{INTRODUCTION}

The decrease in numbers of macrobenthic species from mouth to head of estuaries is well documented: Alexander et al. (1935) gave several examples and many more have appeared since. The distance of penetration of marine species into estuaries has often been correlated with their tolerance of reduced salinities (review: Carriker, 1967), and it is considered axiomatic that reduced and fluctuating salinities result in a harsh restrictive environment which directly reduces diversity, i.e. the communities are physically controlled' in the sense of Sanders (1968). For meiofauna, data on species richness in relation to salinity are conflicting. For the dominant group, the nematodes, Capstick (1959: Table 8) found no marked reduction in species numbers with decreasing salinity on 3 transects in the Blyth estuary, UK. For the next most abundant taxon, the harpacticoid copepods, a reduction in species numbers has, however, been noted in several instances (Noodt, 1957; Reid, 1970 and Brickman, 1972 both cited by Coull, 1973).

Huston (1979) has questioned the validity of environmental stress in explaining all examples of low diver- sity, 'particularly since the inevitable result of natural selection is to minimise the effect of such stress on an organism'. Levinton (1982, p. 95) also recognised the logical difficulty with respect to estuaries: if some species have adapted to these conditions, then why not others? Estuaries are claimed to be one of the most productive non-cultivated ecosystems on earth (Odum, 1971), and lowered diversity is consistent with Huston's dynamic equilibrium model which predicts that competitive exclusion will result in lowered diversity in areas of high productivity. This is supported by the findings of Caswell (1976) who derived models of community structure that did not involve interactions such as competition between species and found that tropical bird, insect and tree communities, which are traditionally regarded as stable climax communities, consistently had diversities lower than neutral model predictions, suggesting that biological interactions depressed diversity. A suggested test for equilibrium or non-equilibrium community structure is the agreement or otherwise between species abundance patterns and the lognormal distribution considered characteristic of equilibrium communities (Ugland and Gray, 1982).

This paper describes meiobenthic community struc- 
ture in intertidal mudflats in the Tamar estuary which are subjected to different salinity regimes and speculates on the underlying causes of the observed patterns in the light of these conflicting hypotheses.

\section{AREA OF INVESTIGATION AND METHODS}

Three sites were selected for study: West Mud near the mouth of the estuary, Neal Point in mid-estuary, and Clifton which is the highest point in the estuary where true intertidal mudflats are present (Fig. 1). The West Mud and Neal Point stations were situated at MTL, but the Clifton station was slightly above this as here the mid-tide level corresponded with the steeply shelving and strongly scoured edge of the river channel, the main area of flats being at a higher level. The sites were chosen to have a closely similar sediment composition. Sediment cores $(3 \times 22 \mathrm{~mm}$ internal di-

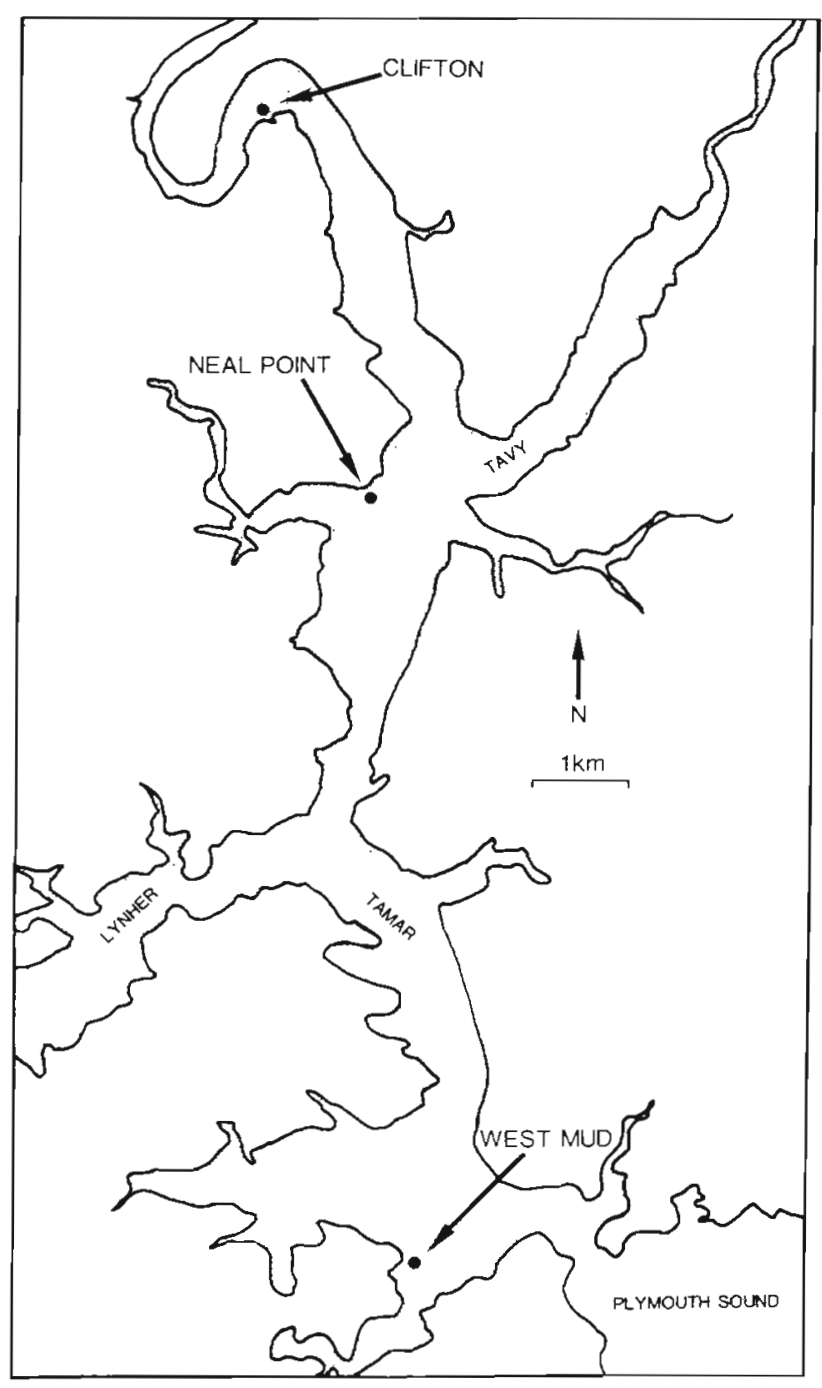

Fig. 1. Location of sampling sites in Tamar estuary ameter cores combined) collected in October 1982 and analysed by the methods described by Buchanan (1971) showed that all corresponded to the Wentworth grade 'silt' (Table 1), although the West Mud station was slightly coarser than the other 2 and had a lower organic content (loss in weight on ignition).

Sediment chlorophyll a and phaeopigments were determined on 3 replicate sediment samples from each site in October 1982. Pigments were extracted from $1 \mathrm{~cm}^{3}$ of wet surface $(0$ to $1 \mathrm{~cm}$ ) sediment in $10 \mathrm{ml} 90 \%$ acetone, spun down and the absorbance read on a spectrophotometer. Calculations were according to Strickland and Parsons (1968). Lowest chlorophyll a and phaeopigment concentrations were found at Neal Point, followed by Clifton, with the highest at West Mud (Table 1).

Table 1. Composition and organic content of sediment from 3 sites in the Tamar estuary, October 1982

\begin{tabular}{|c|c|c|c|}
\hline Sediment & West Mud & Neal Pt. & Clifton \\
\hline$\%$ Sand $(>63 \mu \mathrm{m})$ & 13.08 & 6.34 & 6.26 \\
\hline$\%$ Coarse silt $(15.6-63 \mu \mathrm{m})$ & 52.35 & 41.84 & 36.38 \\
\hline$\%$ Fine silt $(4.0-15.6 \mu \mathrm{m})$ & 12.92 & 21.51 & 21.01 \\
\hline$\%$ Clay $(<4 \mu \mathrm{m})$ & 21.64 & 30.30 & 36.36 \\
\hline Median grain size $(\mu \mathrm{m})$ & 34.00 & 14.50 & 11.30 \\
\hline$\%$ Organic matter & 5.43 & 10.27 & 13.47 \\
\hline $\begin{array}{l}\text { Chlorophyll a } \\
\left(\mu \mathrm{gm}^{-3} \text { wet sediment) }\right.\end{array}$ & 10.97 & 3.84 & 6.81 \\
\hline $\begin{array}{l}\text { Phaeopigments } \\
\text { ( } \mu \mathrm{g} \mathrm{\textrm {cm } ^ { - 3 }} \text { wet sediment) }\end{array}$ & 13.27 & 8.70 & 12.52 \\
\hline
\end{tabular}

High-water salinity values computed weekly from run-off data (Uncles et al., 1983) between October 1981 and October 1982 indicate 2 characteristically distinct periods of the year for all 3 sites: a period of relatively low and strongly fluctuating salinities from October to March and a period of higher more stable salinities from April to September (Fig. 2). Salinities show the obvious up-estuary reduction, but summer salinities at Clifton are comparable with winter salinities at Neal Point, although the latter are more variable.

Macrofauna samples collected in April 1982 (5 × $0.1 \mathrm{~m}^{2}$ randomly collected box quadrats sieved at $0.5 \mathrm{~mm}$ ) revealed a substantial macrofauna biomass at Clifton (Fig. 3) comprising mainly large Scrobicularia plana (da Costa) (46 ind. $\mathrm{m}^{-2}$ ) and large numbers of Nereis diversicolor O. F. Muller (3640 ind. $\mathrm{m}^{-2}$ ), with lesser numbers of Corophium volutator (Pallas) (104 ind $\mathrm{m}^{-2}$ ); the mud surface at this site is covered with the characteristic star-like feeding marks of $S$. plana and with the openings of $C$. volutator burrows. At Neal Point the macrofauna was particularly sparse, with low numbers of Nephtys hombergi Lamark (100 ind. $\mathrm{m}^{-2}$ ) and $N$. diversicolor (16 ind. $\mathrm{m}^{-2}$ ). West Mud had a 
Fig. 2. High-water salinity values at the 3 sites from October 1981 to October 1982, computed from runoff data. Arrows: sampling dates

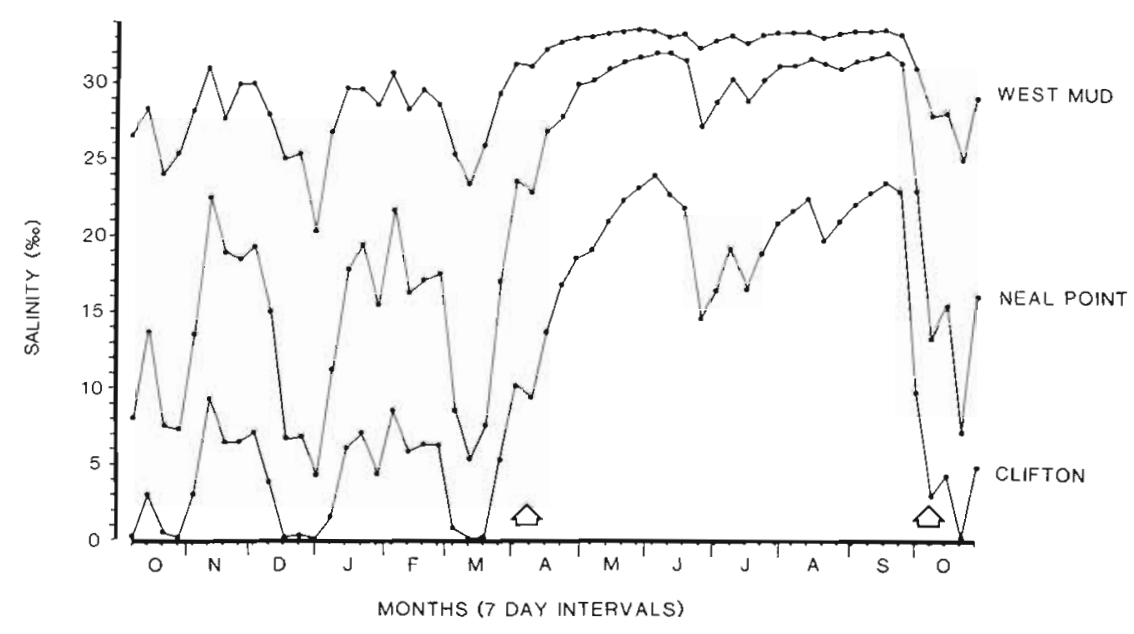

NEAL POINT

WEST MUD
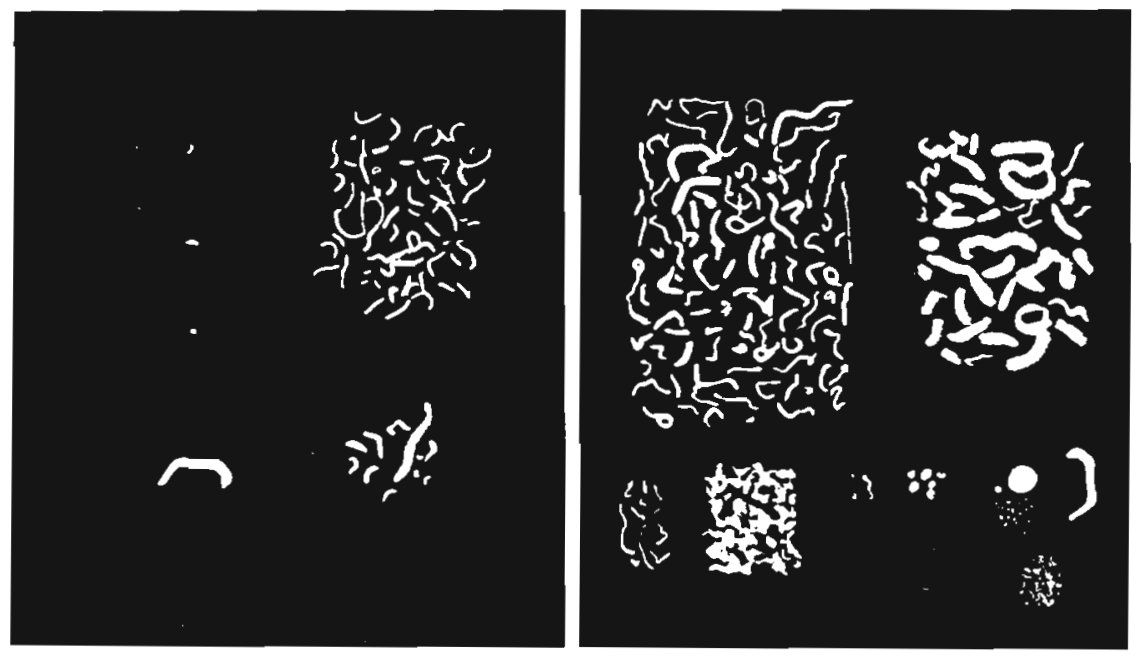

$10 \mathrm{~cm}$

Fig. 3. Photographic silhouettes of macrofauna from an area of $0.5 \mathrm{~m}^{2}$ at each site. Identity of major species can be deduced from text

macrofaunal density and biomass intermediate between Clifton and Neal Point but with many more species present; $N$. hombergi (234 ind. $\mathrm{m}^{-2}$ ), N. diversicolor (26 ind. $\mathrm{m}^{-2}$ ) and Ampharete acutifrons (Grube) (962 ind. $\mathrm{m}^{-2}$ ) were prominent (Fig. 3).

Meiofauna samples were collected in April and October 1982, these dates being preceded respectively by 6 mo periods of low fluctuating salinities and higher more stable salinities (Fig. 2). Each sample set consisted of 6 replicates taken with plastic core tubes (22 $\mathrm{mm}$ internal diameter) to a depth of $10 \mathrm{~cm}$, on a rectangular grid pattern (2 rows of 3 with $8 \mathrm{~cm}$ between centres). The mud samples were preserved in $4 \%$ formalin, stained with Rose Bengal, and the meiofauna extracted with LUDOX-TM according to the methods described by McIntyre and Warwick (1984). Harpacticoid copepods were picked out of the samples as their identification required dissection, and the remaining material (meiofauna plus the small amount of remaining detritus) was mounted in glycerine on a series of microscope slides (McIntyre and Warwick, 1984). The 'soft' meiofauna, chiefly turbellarians in this case, are difficult to identify routinely in preserved samples and our analysis has therefore been confined to the nematodes and copepods which were the dominant taxa. A more comprehensive analysis of all taxa (Warwick, 1984) indicated that these 2 groups comprise $90.5 \%, 97.5 \%$ and $90.3 \%$ of the total number of meiofaunal species at West Mud, Neal Point and Clifton respectively; it is well known that 'soft' 
meiofauna in general are not abundant in fine muddy sediments (McIntyre, 1969).

All the copepods from all the cores were identified and counted. For the nematodes, the total numbers were counted for the April samples and sufficient randomly selected specimens from each core identified for the species area curve to become acceptably flattened (as it was necessary for other purposes to obtain all the species present). From West Mud 1015 specimens were identified, 977 from Neal Point and 527 from Clifton. In October the first 83 randomly selected specimens from 4 cores and 84 from 2 cores, giving a total of 500, were identified from each site. For comparison, the April sample sizes were reduced to 500 individuals using the rarefaction method of Sanders (1968) (see Simberloff, 1972). Biomasses of each species were determined from volume calculations. For each species the length $\times$ maximum width squared (in $\mathrm{mm}$ ) was calculated and multiplied by a conversion factor to give body volumes in $\mathrm{nl}$. For nematodes a common factor of 530 was applied (Warwick and Price, 1979). For the copepods each species was categorised visually into one of eight body forms, and conversion factors applied which were derived from scale models in plasticene (see McIntyre and Warwick, 1984). These conversion factors are given in Fig. 4. The proportion of total biomass attributable to each species was calculated by multiplying the total numbers present by the adult

$\begin{array}{cc}\text { Cylindrical } & \text { Semi-Cylindrical } \\ 750 & \text { Compressed }\end{array}$

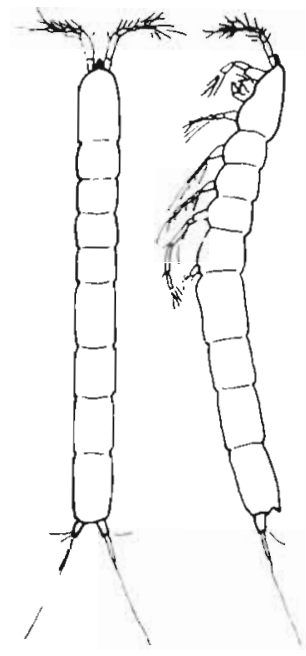

Fusiform

485

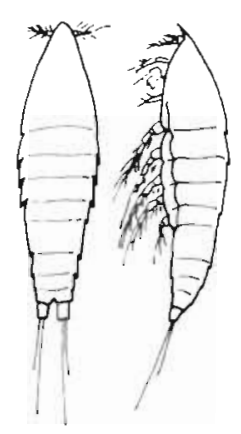

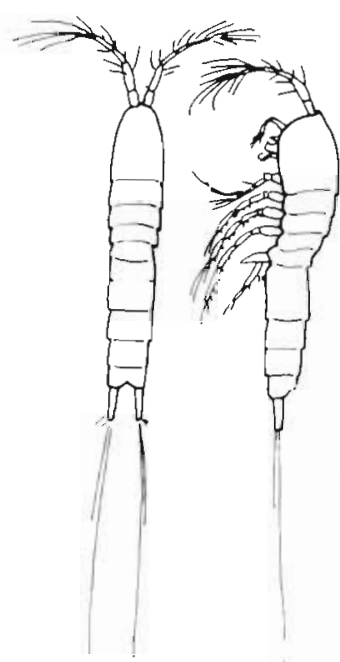

Pyriform

400
Semi-Cylindrical

560

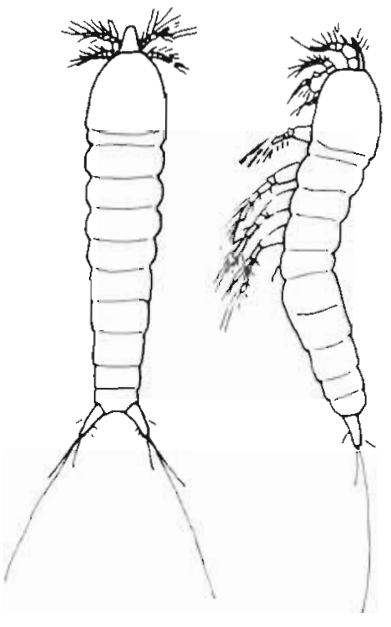

Pyriform Depressed

260

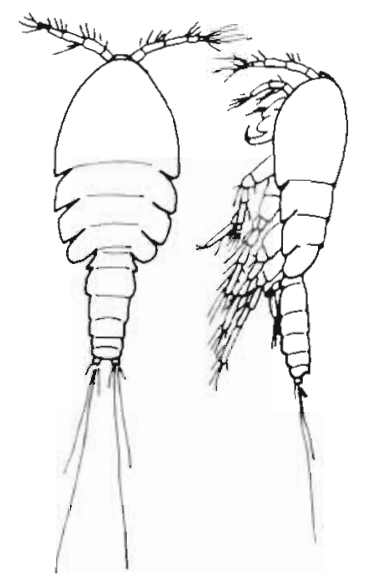

Semi-Cylindrical

Depressed

490
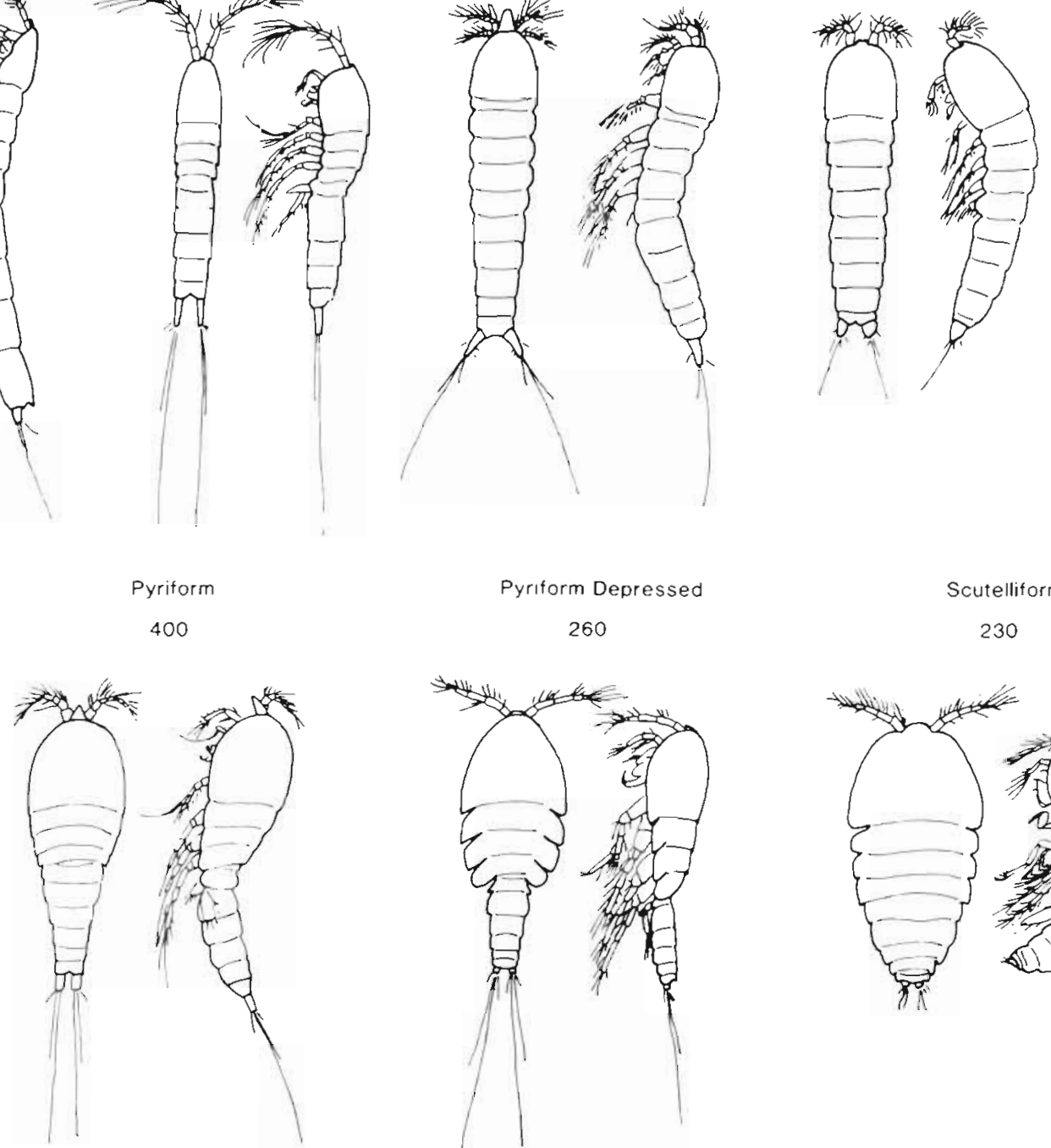

Fig. 4. Outlines of harpacticoid copepod body forms with conversion factors (C) in the equation: body volume (nl) $=$ length $X$ width ${ }^{2}(\mathrm{~mm}) \times \mathrm{C}$ 
body volume, which makes the assumptions that the size distribution relative to the size of the adult is the same for each species, as is the conversion factor from volume to biomass.

To compare community structure between sites, ranked species abundance curves and ranked species biomass curves were plotted and compared with the theoretical lognormal distribution (Whittaker, 1970; May, 1975). The Shannon Wiener diversity index $\left(\mathrm{H}^{\prime}\right)$ was also calculated and compared with predicted values from a neutral model (Caswell, 1976) using a modified version of the computer programme developed by Ewens (1972).

\section{RESULTS}

Numbers of nematode and copepod species from the 3 stations are detailed in the Appendix. Total meiofaunal abundance (nematodes + copepods) was much higher at both West Mud and Neal Point (April values $5.97 \times 10^{6}$ and $6.06 \times 10^{6} \mathrm{~m}^{-2}$ respectively) than at Clifton $\left(1.41 \times 10^{6} \mathrm{~m}^{-2}\right)$.

Ranked species abundance curves (Fig. 5) show that, in April, harpacticoid copepods follow the conventional pattern in relation to the salinity gradient: West Mud, the most saline station, has the shallowest sloping curve (highest number of species, low dominance), followed by Neal Point, with Clifton, the lowest salinity station, having the steepest curve with very few species and high dominance. Nematodes, on the other hand, do not follow this pattern: although West Mud again has the shallowest slope, the gradients at Neal Point and Clifton are reversed, with Neal Point steeper than Clifton. Because nematodes are the more abundant and diverse taxon, the 'total meiofauna' (nematodes + copepods) curve has a pattern similar to that of the nematodes alone. In October the nematode pattern is unchanged from April, but copepods show a reversal of the Neal Point and Clifton gradients, with Neal Point steeper than Clifton as for nematodes. Inspection of species lists (Appendix) shows that the copepod fauna at Clifton in October was similar to that of Neal Point in April.

Species abundances have been converted to biomass in Fig. 6. For economy of space, only the April ranked species biomass curves are presented, which are sufficient to indicate an almost identical pattern to the abundance curves, although of course the species ranking is somewhat different.

Species diversity (Table 2) follows the trends expected from visual inspection of the ranked species abundance curves. For nematodes, diversity is highest at West Mud, followed by Clifton, with Neal Point the lowest both in April and October. Copepod diversities are not strictly comparable because of the different numbers used for each calculation, but show a trend of decreasing diversity from West Mud to Clifton in April, but with a lower diversity at Neal Point than Clifton in October despite the much lower numbers at Clifton. For the most part, measured diversity is close to neutral model predictions (Table 2), but nematode diversity was lower than predicted at Neal Point (significantly so in April) and copepod diversity was significantly higher than predicted at West Mud in October.

The fit of the nematode species abundance curves to the theoretical lognormal distribution (Fig. 7) shows a clear trend both in April and October. The fit is generally good at West Mud and poor at Neal Point, where the common species are too abundant and the less common species too rare. Clifton data fit the lognormal quite well, except that in April rare species are less abundant than predicted. Bearing in mind the variability in copepod sample sizes, data for copepods show a good fit to the lognormal, except at West Mud in October where the 2 most abundant species are rarer than predicted, and the less common species too abundant.

\section{DISCUSSION}

Observations that at Neal Point nematodes have the steepest ranked species abundance and biomass curves, the lowest diversity (below neutral model predictions) and the greatest departure from the lognormal distribution are not consistent with salinity being the major structuring force. For copepods, these aspects of community structure follow the salinity pattern more closely, but diversity is depressed at Clifton only after very low fluctuating winter salinities, and the pattern at the end of the summer is the same as that observed for the nematodes.

As noted earlier, the dominant copepod species at Clifton in October (Microarthridion fallax, Amphiascoides limicola, Stenhelia palustris) were not present at this site in April but were the dominant species at Neal Point in that month. This implies an upstream migration of some copepod species corresponding to the changed summer salinity at Clifton (similar to winter salinity at Neal Point). A possible mechanism for this faunal change could be the tidal resuspension (Bell and Sherman, 1980; Palmer and Brandt, 1981) and transport of meiofauna (and sediment) from the middle to the upper reaches of the estuary during the summer. Bale (pers. comm.) has evidence that there is a net upstream movement of sediment in the estuary during the summer and a net downstream movement in the autumn and early winter. However, none of the dominant nematodes at Neal Point in April were found in increased abundance at Clifton in October, except 

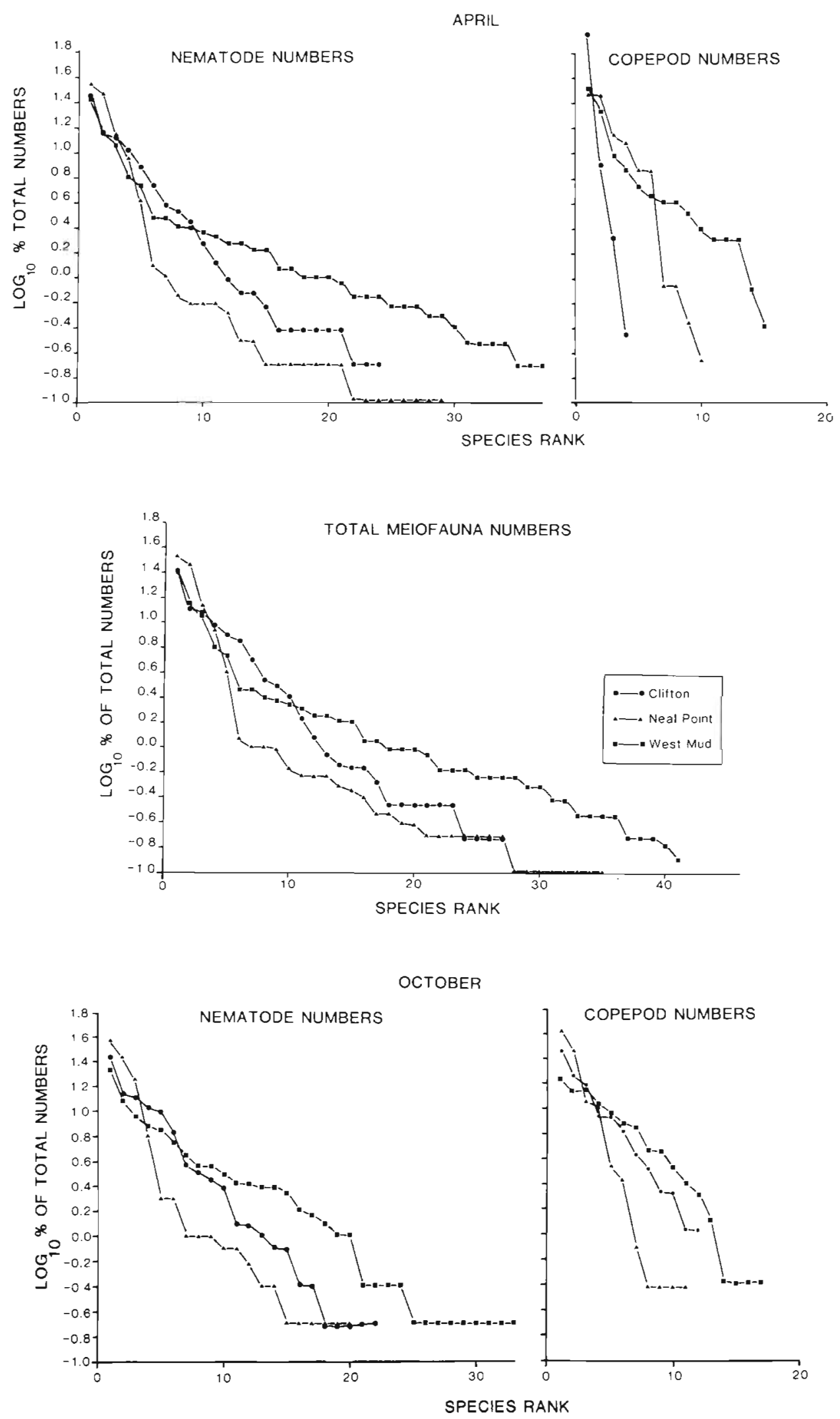

Fig. 5. Ranked species abundance curves for April and October 

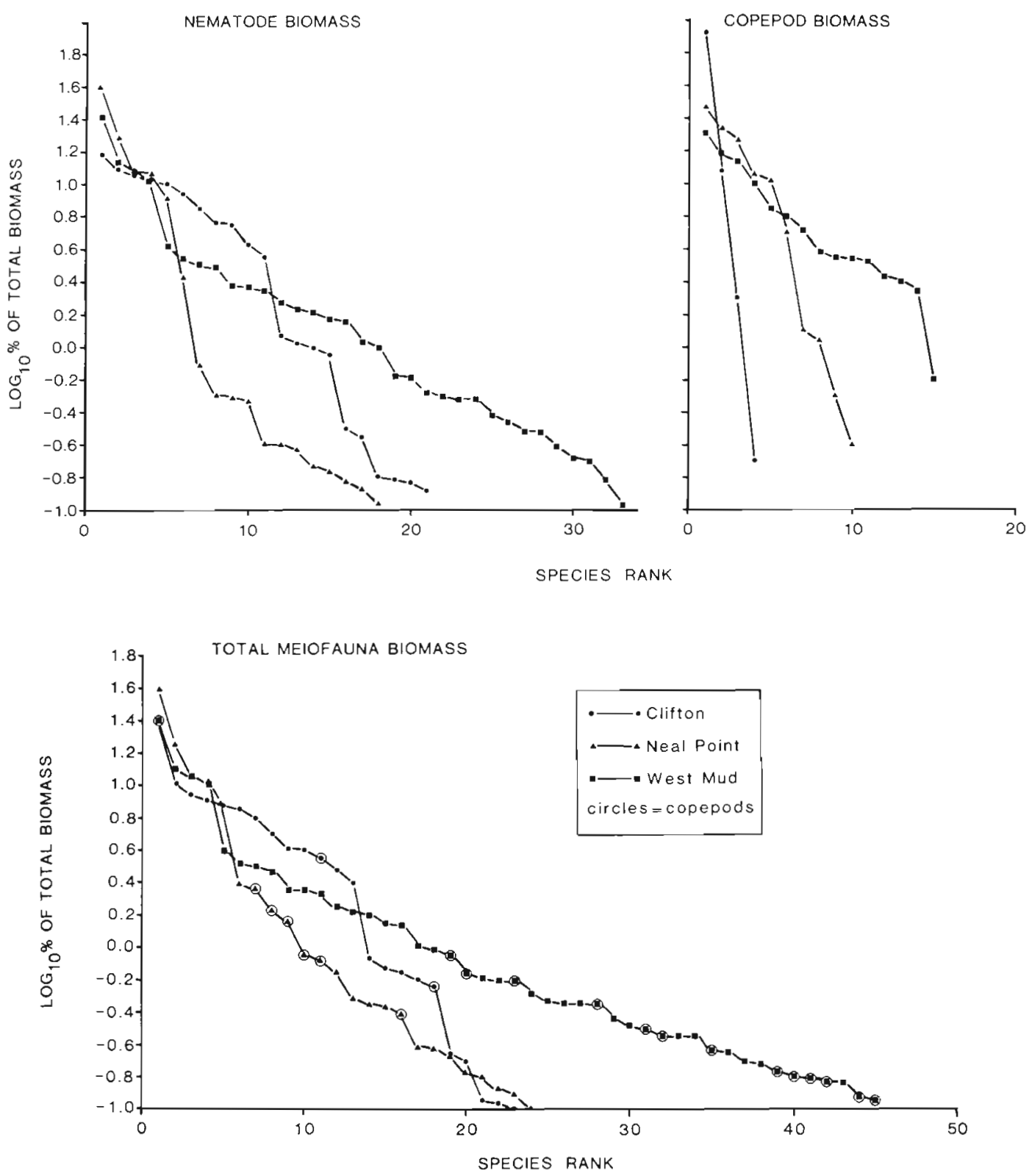

Fig. 6. Ranked species biomass curves for April

for Ptycholaimellus ponticus (see Appendix). The possibility that copepods and $P$. ponticus were more amenable to suspension by virtue of their more surficial distribution in the sediment led us to collect samples at Neal Point in October 1983 with a micrometer corer (Joint et al., 1982), sectioning the cores at $1 \mathrm{~mm}$ intervals. Distributions in the top $15 \mathrm{~mm}$ of sediment (Fig. 8 and 9) show a distinct fine-scale vertical zonation with the above mentioned copepod species and the nematode $P$. ponticus having centres of distribution in the top few mm of sediment whereas copepods of the genus Enhydrosoma and the remaining dominant nematodes were found deeper than this. Metachromadora vivipara had the shallowest subsurface dis- tribution, Terschellingia longicaudata and T. communis were confined to deeper layers and Sebatieria pulchra had only just begun to appear in the cores at $15 \mathrm{~mm}$. Deeper cores showed that these last 3 species penetrated to a depth of $35 \mathrm{~mm}$. Passive resuspension and transport is thus a likely mechanism for the observed differences at Clifton in April and October.

The apparent anomaly of higher diversity at Clifton than Neal Point is consistent with Huston's (1979) dynamic equilibrium hypothesis. Huston suggested that most communities are in a non-equilibrium state. Competitive equilibrium, with its consequent reduction or exclusion of some species, is prevented by periodic population reductions and environmental 
Table 2. Measured diversity indices $\left(\mathrm{H}^{\prime}\right)$ for nematodes and copepods from 3 sites in the Tamar estuary compared with expected indices, $E\left(H^{\prime}\right)$, from neutral model predictions (Caswell, 1976)

\begin{tabular}{|c|c|c|c|c|c|c|}
\hline \multicolumn{7}{|c|}{ Nematodes (all based on 500 individuals) } \\
\hline & \multicolumn{2}{|c|}{ West Mud } & \multicolumn{2}{|c|}{ Neal Point } & \multicolumn{2}{|c|}{ Clifton } \\
\hline & Apr & Oct & Apr & Oct & Apr & Oct \\
\hline $\mathrm{H}^{\prime}$ & 2.704 & 2.761 & 1.788 & 1.726 & 2.297 & 2.296 \\
\hline $\mathrm{E}\left(\mathrm{H}^{\prime}\right)$ & 2.825 & 2.654 & 2.331 & 2.081 & 2.284 & 2.187 \\
\hline$F$ test & NS & NS & $\cdot$ & NS & NS & NS \\
\hline \multicolumn{7}{|c|}{ Copepods (based on numbers as given) } \\
\hline & \multicolumn{2}{|c|}{ West mud } & \multicolumn{2}{|c|}{ Neal point } & \multicolumn{2}{|c|}{ Clifton } \\
\hline & Apr & Oct & Apr & Oct & Apr & Oct \\
\hline Number & 249 & 240 & 469 & 261 & 288 & 93 \\
\hline $\mathrm{H}^{\prime}$ & 2.149 & 2.410 & 1.734 & 1.536 & 0.401 & 2.062 \\
\hline$E\left(H^{\prime}\right)$ & 1.908 & 2.055 & 1.377 & 1.568 & 0.671 & 1.880 \\
\hline$F$ test & NS & 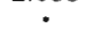 & NS & NS & NS & NS \\
\hline
\end{tabular}

fluctuations, and a stable level of diversity can be maintained by the dynamic balance between the rate of competitive displacement and the frequency of population reduction. Under stable conditions, where population reductions are infrequent, competitive equilibrium is approached and diversity decreased. At Clifton meiofaunal densities are low, possibly due to predation and/or sediment disturbance by the high density of macrofauna, or to more pronounced environmental fluctuations. We suggest that competitive equilibrium is not approached and a high diversity is therefore maintained. At Neal Point population densities are high, predation and disturbance by macrofauna virtually non-existent, and environmental fluctuations less intense. Here, therefore, competitive exclusion is more likely to be the cause of lowered diversity. This argument is perhaps rather less applicable to the copepods than to the nematodes, by virtue of their generally more surficial vertical distribution and susceptibility to passive transport in the water column. Densities of copepod species are thus less likely to be dependent on local predation pressures and there is likely to be a larger measure of physical control of community structure than for the nematodes.

If the meiofauna at Clifton comprise a non-equilibrium or successional community, and at Neal Point an equilibrium or climax community, this would be expected to reflect in the life-history characteristics of the dominant species at the 2 sites. We know very little about these characteristics, but Warwick and Price (1979) have measured the respiration rates of many of the nematode species, and it is probable that these rates are positively correlated with rates of production (Humphreys, 1979). Also, the feeding behavior of the nematodes can be deduced from the structure of the buccal cavity (Wieser, 1953). Fig. 10 shows the dominance of species with very low respiration rates, and hence probably long generation times, at Neal Point, and the preponderance of species with high respiration rates at Clifton. The 3 commonest species at Clifton are the chromadorids Ptycholaimellus ponticus, Dichromadora cephalata and Hypodontolaimus geophila which have buccal cavities armed with a strong dorsal tooth. These chromadorids are known to be diatom feeders (von Thun, 1968; Jensen, 1982) and it is well known that they are easy to culture in the laboratory, being regarded as exploititive opportunistic 'laboratory weeds'. The fourth most abundant species, the Oncholaimid Viscosia viscosa, has a predator/omnivore buccal cavity (Type 2B of Wieser, 1953) and the highest respiration rate of all the species studied by Warwick and Price (1979): oncholaimids are also noted for their relative ease of laboratory culture and may also be regarded as opportunists. The dominant species at Neal Point, Metachromadora vivipara, also has a buccal cavity armed with a dorsal tooth and may be a diatom feeder, but it reaches maximum abundance a few $\mathrm{mm}$ below the sediment surface and has the lowest respiration rate of all the species studied by Warwick and Price. Attempts to cultivate it in the laboratory have proved unsuccessful, and its viviparous habit may be further indicative of its conservativeness. Two species of Terschellingia found deeper in the sediment are probably selective bacterial feeders with a very small unarmed buccal cavity (Wieser's Group 1A) and low respiration rates. The fourth and deepest living species, the comesomatid Sabatieria pulchra, has a cup-shaped but unarmed buccal cavity 
NEMATODES

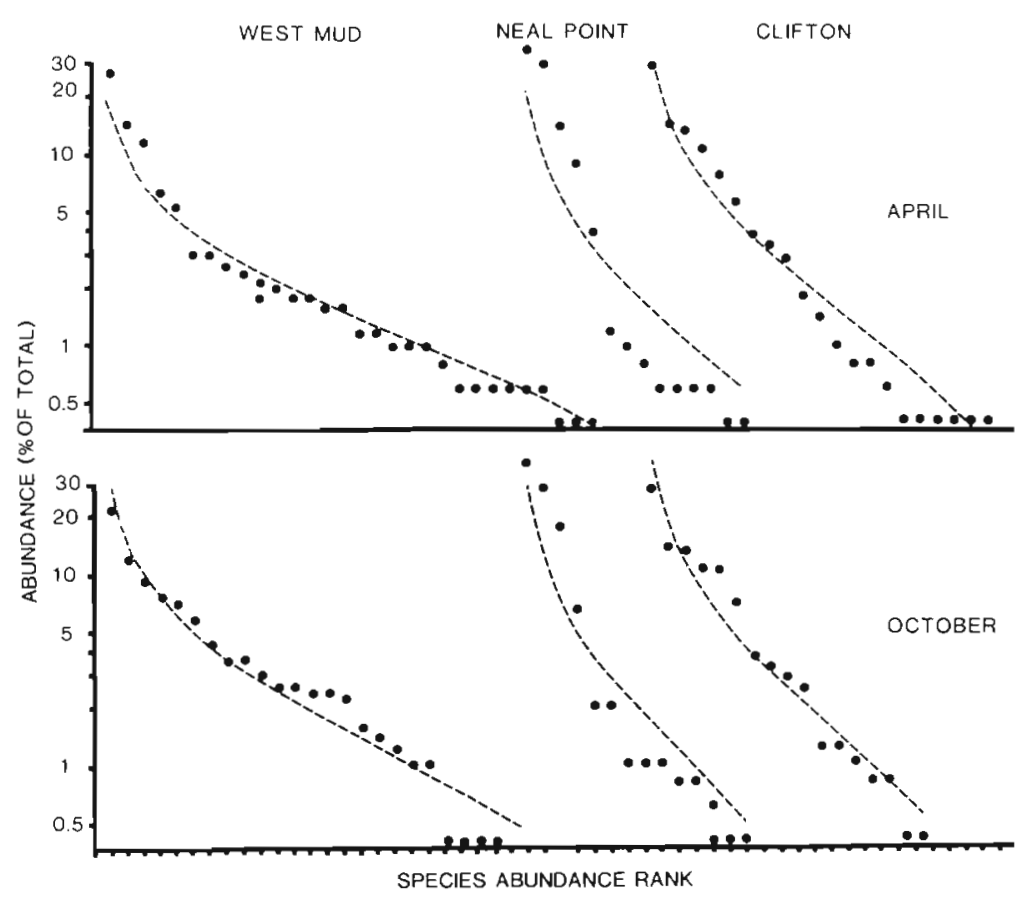

COPEPODS

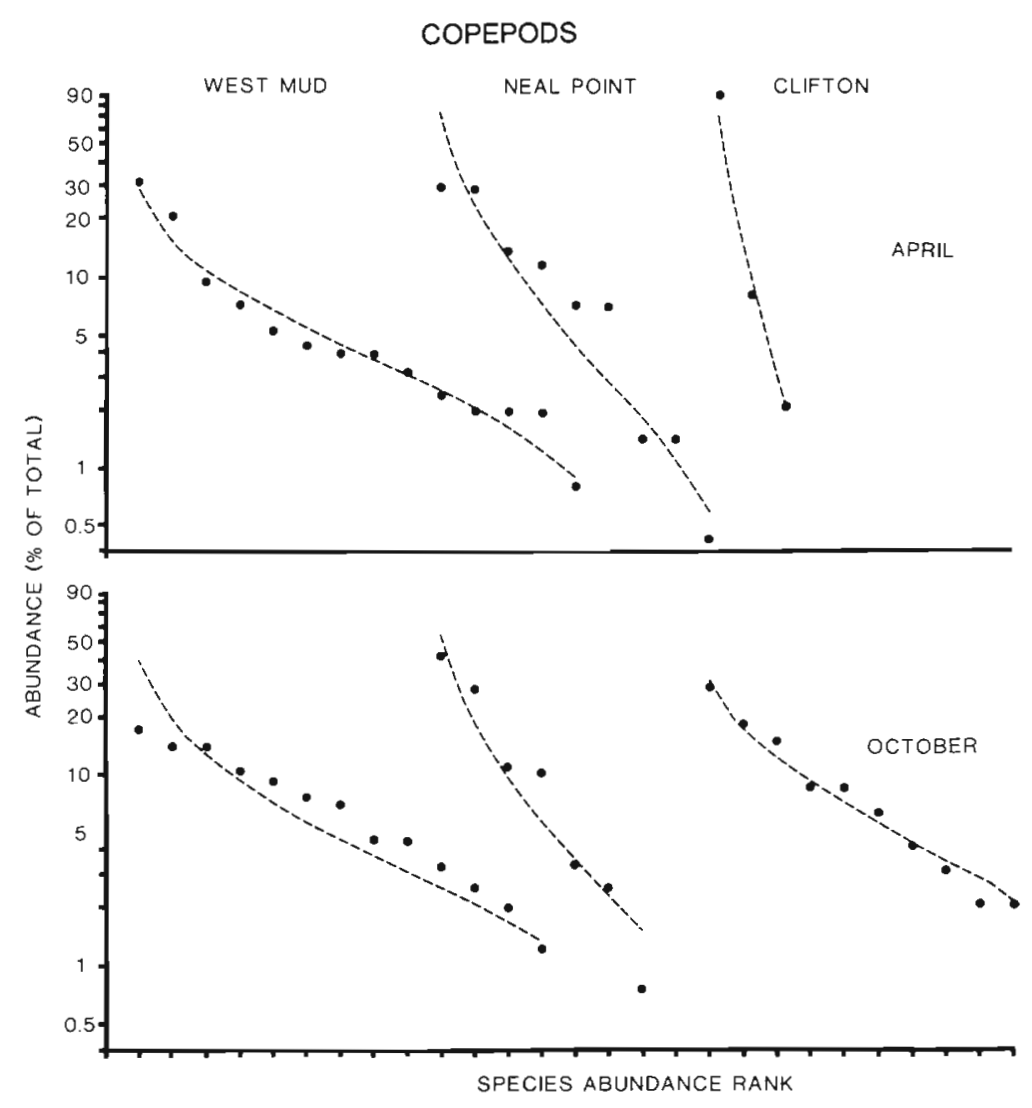

Fig. 7. Ranked species abundance curves showing fit to the theoretical lognormal distribution (broken lines)

and is regarded as a 'non-selective deposit-feeder' (Wieser's Group 1B), again with a low respiration rate. Comesomatids are dominant in offshore muds and many are found in reduced layers of sediment: $S$. pulchra is one of the few metazoans surviving the oxygen deficient sediments of the Baltic (Jensen, 


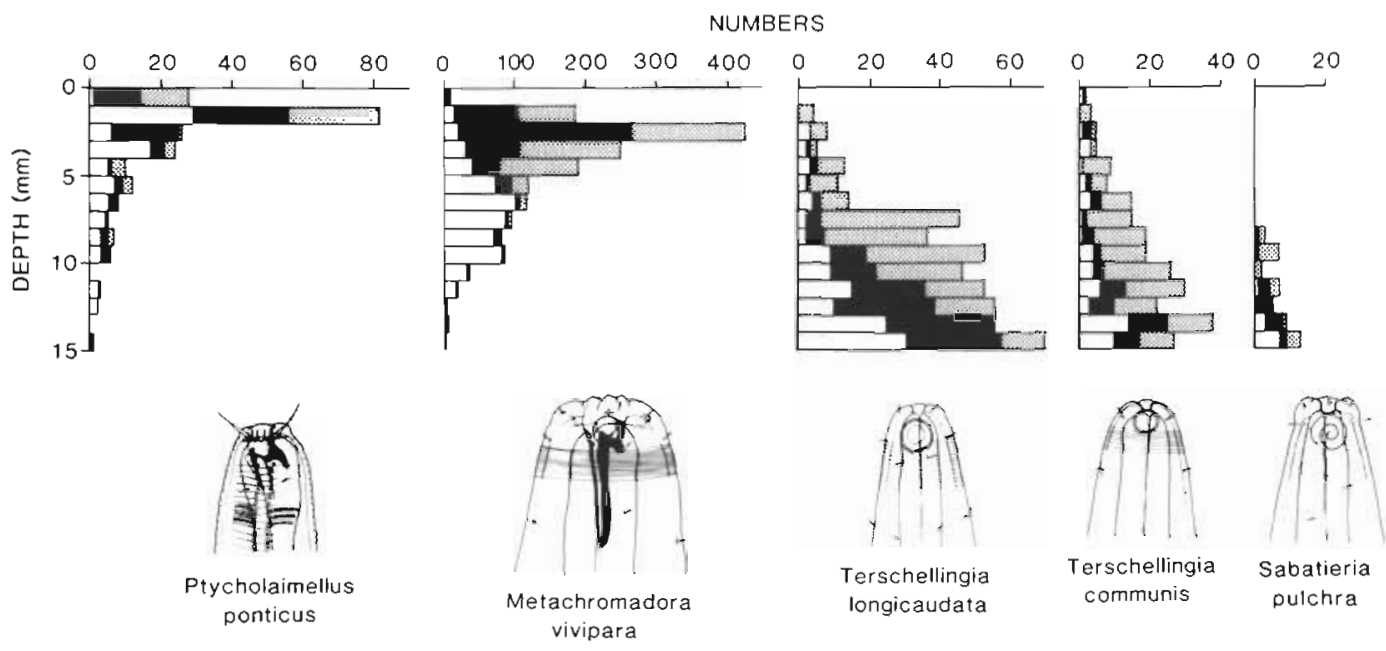

Fig. 8. Fine-scale depth distribution of major nematode species at Neal Point. Note difference in abundance scale between Metachromadora vivipara and remaining species. Shading conventions represent numbers in separate replicate 22 inm cores. Nematode heads drawn to scale to show buccal structures

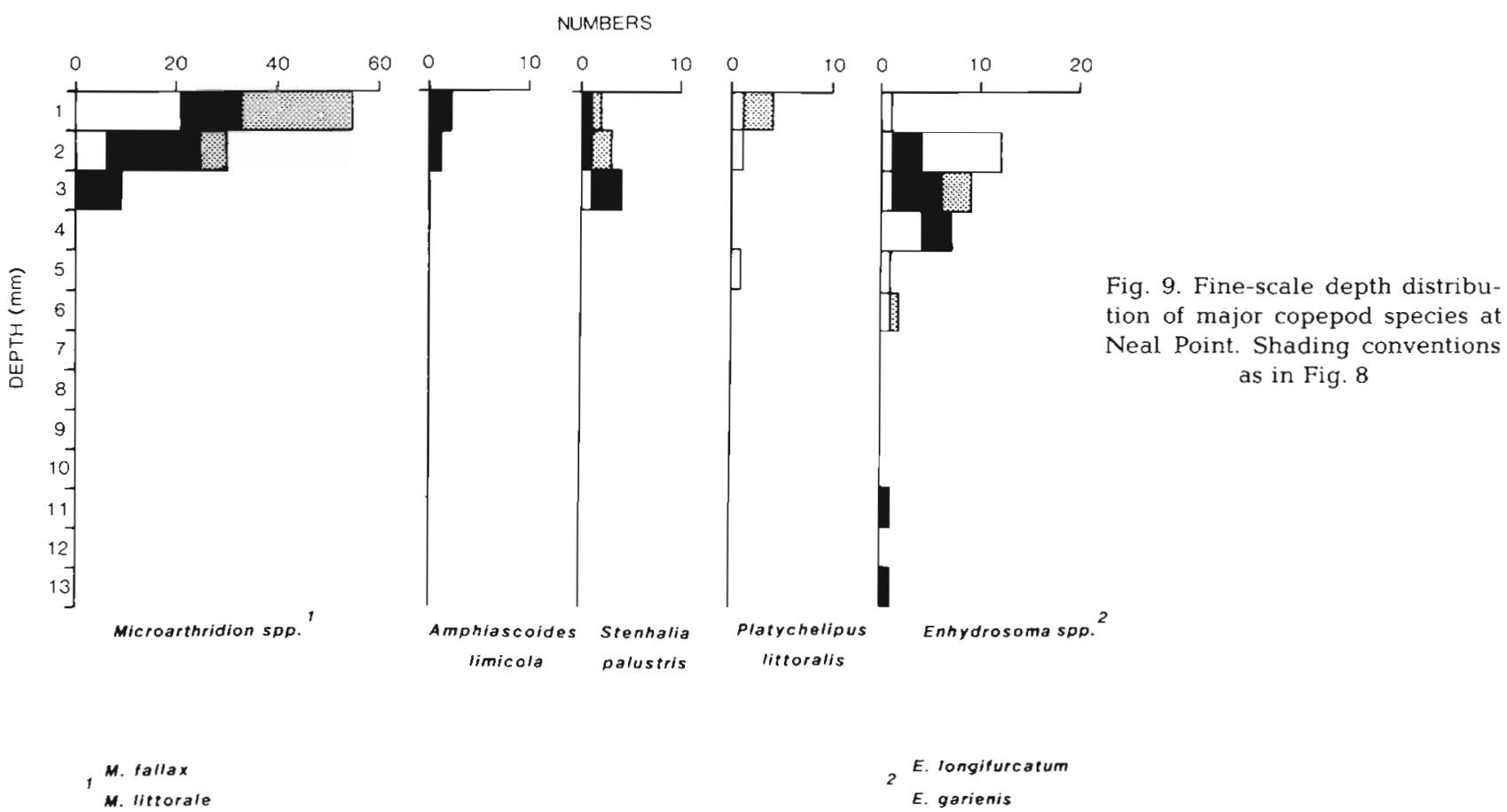

1981). They have been the subject of many unsuccessful attempts to culture in the laboratory (Jensen, pers. comm.; own obs.), as have Terschellingia species.

This circumstantial evidence suggests that Clifton is dominated by opportunistic and Neal Point by conservative nematode species, supporting the view that Neal Point is a more stable climax community and Clifton a non-equilibrium successional one. At Neal Point, diversity at any particular depth horizon is even lower than suggested from calculations based on the entire depth-integrated community, because of the fine-scale vertical stratification of species present there which is successfully maintained in the absence of macrofaunal 'bioturbation'.

At West Mud, several of the conservative Neal Point nematode species are dominant ( $S$. pulchra, Terschellingia spp., $M$. vivipara), but opportunistic species are also present in higher proportions than at Neal Point. If our reasoning regarding the Neal Point and Clifton communities is correct, this would represent a later successional stage, i.e. a transition between the early successional community at Clifton and the climax community at Neal point. This produces high diversity, in one case (copepods in October) above neutral model 
Fig. 10. Bar chart showing mean (April and October) percentage dominance of the nematode species for which respiration rates were determined by Warwick and Price (1979), with species ranked in decreasing order of respiratory intensity ( $\mathrm{a}=$ intercept of equation $\mathrm{R}=\mathrm{aV}^{0.75}$, where $\mathrm{R}=\mathrm{nl} \mathrm{O}$ ind $^{-1} \mathrm{~h}^{-1}$ at $20^{\circ} \mathrm{C}$;

$$
\mathrm{V}=\mathrm{nl})
$$

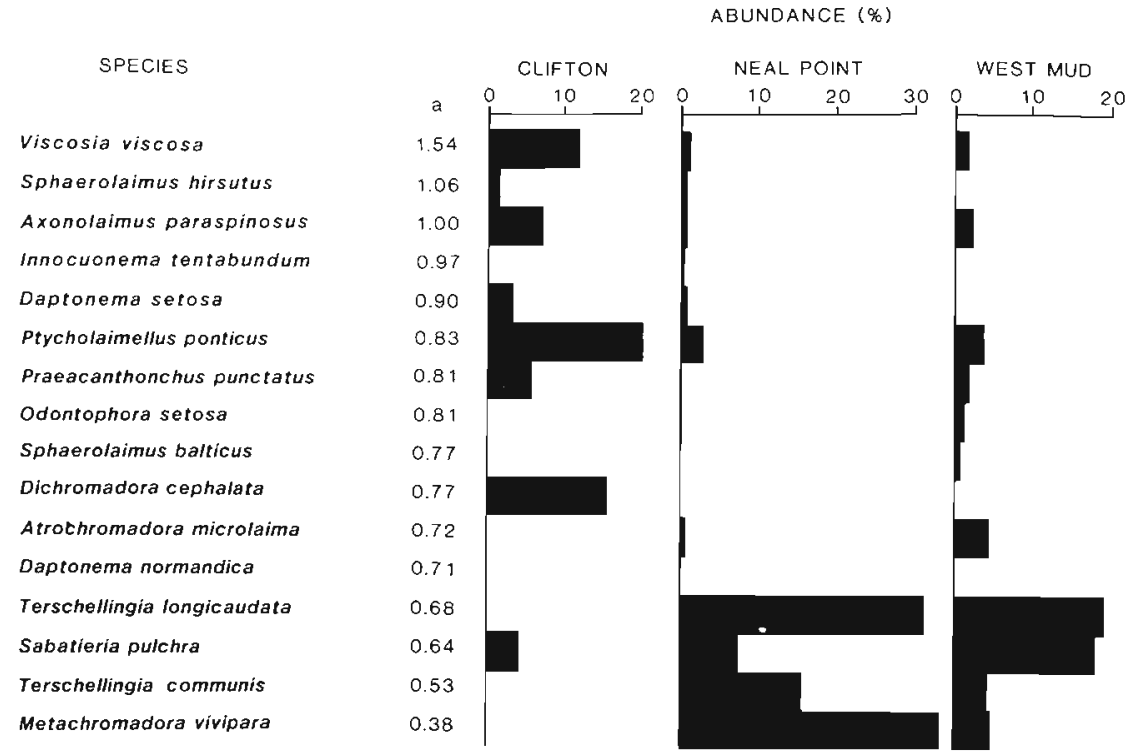

predictions with a departure from the lognormal distribution resulting from the common species being too rare and the rare species too common. This transitional stage may relate to an intermediate level of macrofaunal predation. However, in the case of West Mud these arguments are admittedly weakened by the well documented observation that nematode diversity is higher in coarser sediments (Weiser, 1960; Hopper and Meyers, 1967; Warwick, 1971) although this does not appear to be the case for copepods (Coull and Fleeger, 1977; Bell, 1979; Fleeger, 1980). The sediment at West Mud is slightly coarser than at the other two stations.

Agreement of species abundance distributions with the lognormal distribution is usually explained in terms of the Central Limit Thoerem, species abundance being assumed to depend multiplicatively on a number of factors (Routledge, 1980). Evidence presented here would imply that such conditions do not apply to climax communities where competitive exclusion is a dominant structuring force.
The potential importance of biological interactions between species, both within the meiofauna and between the meiofauna and macrofauna, is contrary to the traditional view of estuaries as harsh environments where community structure is physically controlled: Although our explanations of the observed patterns of community structure are necessarily speculative, all the field evidence presently available supports Huston's dynamic equilibrium hypothesis, the predictions of which are testable by controlled field and laboratory experiments. These will form the next phase of study in the Tamar.

Acknowledgements. We thank Jacky Murgatroyd for technical assistance; John Davey and Chris George for help in collecting and processing macrofauna samples; Alan Pomroy for Chlorophyll analyses and Reg Uncles for generating salinity data. This work forms part of the benthic ecology programme of the Institute for Marine Environmental Research, a component of the Natural Environment Research Council.

\section{APPENDIX}

Total numbers of nematodes in subsamples of 6 cores from 3 sites in the Tamar estuary. Bracketed figures for April represent total number reduced to a sample size of 500 by rarefaction. Nomenclature follows Gerlach and Riemann $(1973,1974)$, with modifications by Lorenzen (1981)

\begin{tabular}{|c|c|c|c|c|c|c|c|c|}
\hline \multirow[t]{2}{*}{ Species } & \multicolumn{2}{|c|}{ Clifton } & \multicolumn{3}{|c|}{ Neal Point } & \multicolumn{3}{|c|}{ West Mud } \\
\hline & Apr & Oct & Apr & & Oct & & & Oct \\
\hline \multicolumn{9}{|l|}{ Anoplostomatidae } \\
\hline Anoplostoma viviparum & (3) & - & 1 & $(-)$ & - & 30 & (15) & 8 \\
\hline \multicolumn{9}{|l|}{ Oxystominidae } \\
\hline Halalaimus gracilis & - & 6 & 2 & (1) & 1 & 7 & (3) & 2 \\
\hline Halalaimus sp. & - & - & - & & - & 10 & (5) & - \\
\hline
\end{tabular}


Appendix (continued)

\begin{tabular}{|c|c|c|c|c|c|c|c|c|c|}
\hline \multirow[t]{2}{*}{ Species } & \multicolumn{3}{|c|}{ Clifton } & \multicolumn{3}{|c|}{ Neal Point } & \multicolumn{3}{|c|}{ West Mud } \\
\hline & Apr & & Oct & Apr & & Oct & Apr & & Oct \\
\hline \multicolumn{10}{|l|}{ Oxystominidae } \\
\hline Nemanema cylindraticaudatum & 2 & $(2)$ & - & - & & - & - & & - \\
\hline Oxystomina elongata & 1 & (1) & - & - & & 1 & - & & - \\
\hline \multicolumn{10}{|l|}{ Oncholaimidae } \\
\hline $\begin{array}{l}\text { Viscosia abyssonum } \\
\text { Viscosia viscosa }\end{array}$ & - & & - & - & & - & 6 & (3) & - \\
\hline Viscosia viscosa & 56 & (53) & 65 & 12 & (6) & 4 & 9 & (4) & 15 \\
\hline \multicolumn{10}{|l|}{ Enchelidiidae } \\
\hline Calyptronema maxweberi & 5 & (5) & - & - & & - & - & & 1 \\
\hline \multicolumn{10}{|l|}{ Tripyloididae } \\
\hline \multicolumn{3}{|l|}{ Chromadoridae } & - & - & & - & 3 & (1) & \\
\hline Atrochromadora microlaima & - & & - & 6 & (3) & 5 & 25 & (12) & 35 \\
\hline Dichromadora cephalata & 154 & (146) & 12 & - & & - & - & & - \\
\hline Hypodontoiaimus balticus & - & & 5 & 2 & $(1)$ & - & 1 & $(-)$ & 1 \\
\hline Hypodontolaimus geophila & 76 & $(72)$ & 67 & 2 & (1) & - & 5 & (2) & - \\
\hline Innocuonema tentabundum & - & & 1 & - & & 4 & - & & - \\
\hline Neochromadora sp. & - & & - & 1 & $(-)$ & - & 7 & (3) & - \\
\hline Ptycholaimellus ponticus & 70 & (66) & 137 & 40 & $(20)$ & 10 & 21 & (10) & 29 \\
\hline Spilophorella paradoxa & 2 & $(2)$ & - & - & & - & 1 & (1) & 1 \\
\hline \multicolumn{10}{|l|}{ Ethmolaimidae } \\
\hline Neotonchus sp. & - & & - & - & & - & 12 & (6) & 2 \\
\hline \multicolumn{10}{|l|}{ Cyatholaimidae } \\
\hline Paracanthonchus aff. caecus & - & & - & - & & - & 3 & (1) & 1 \\
\hline Praeacanthonchus punctatus & 7 & (7) & 52 & 2 & (1) & - & 10 & (5) & 13 \\
\hline \multicolumn{10}{|l|}{ Comesomatidae } \\
\hline Paracomesoma sp. & - & & - & - & & - & 12 & (6) & 12 \\
\hline Sabatieria celtica & - & & - & - & & - & 17 & (8) & 18 \\
\hline Sabatieria hilarula & - & & - & - & & - & 6 & (3) & - \\
\hline Sabatieria pulchra & 29 & $(28)$ & 16 & 87 & $(45)$ & 32 & 146 & $(72)$ & 109 \\
\hline \multicolumn{10}{|l|}{ Desmodoridae } \\
\hline Desmodora sp. A & - & & - & - & & - & 1 & $(-)$ & - \\
\hline Desmodora sp. B & - & & - & - & & - & 1 & $(-)$ & - \\
\hline Metachromadora vivipara & 2 & (2) & - & 289 & $(148)$ & 186 & 55 & $(27)$ & 22 \\
\hline Molgolaimus tenuispiculum & - & & - & - & & - & 17 & (8) & 46 \\
\hline Spirinia parasitifera & - & & - & 1 & (1) & - & 10 & (5) & 11 \\
\hline \multicolumn{10}{|l|}{ Microlaimidae } \\
\hline Aponema torosa & 2 & $(2)$ & 1 & 2 & (1) & 10 & - & & - \\
\hline Microlaimus honestus & - & & - & - & & 1 & 65 & $(32)$ & 18 \\
\hline Microlaimus robustidens & 1 & (1) & - & - & & - & - & & - \\
\hline \multicolumn{10}{|l|}{ Monoposthiidae } \\
\hline Nudora bipapillata & - & & - & - & & - & 117 & $(58)$ & 12 \\
\hline \multicolumn{10}{|l|}{ Leptolaimidae } \\
\hline Leptolaimus limicolus & - & & 1 & - & & - & - & & - \\
\hline Leptolaimus papilliger & 10 & (9) & 4 & 1 & $(-)$ & - & 1 & $(-)$ & - \\
\hline Aegialoalaimidae & & & & & & & & & \\
\hline Áegialoalaimus elegans & - & & 1 & - & & - & - & & - \\
\hline Desmoscolecidae & & & & & & & & & \\
\hline Calligyrus sp. & 4 & (4) & - & - & & - & - & & - \\
\hline Desmoscolex falcatus & 1 & (1) & 1 & 1 & $(-)$ & - & 30 & (15) & 2 \\
\hline Tricoma sp. & - & & - & 1 & (1) & - & 6 & (3) & - \\
\hline Xyalidae & & & & & & & & & \\
\hline Daptonema normandica & - & & - & 3 & (2) & - & 3 & (1) & - \\
\hline Daptonema oxycerca & - & & 51 & 3 & (2) & 2 & 5 & $(2)$ & - \\
\hline Daptonema procera & 20 & (19) & 4 & 7 & (4) & 3 & 2 & (1) & 7 \\
\hline Daptonema setosa & 18 & (17) & 18 & 10 & (5) & 2 & 4 & $(2)$ & 1 \\
\hline Theristus acer & - & & - & 2 & (1) & - & - & & - \\
\hline
\end{tabular}


Appendix (continued)

\begin{tabular}{|c|c|c|c|c|c|c|c|c|c|}
\hline \multirow[t]{2}{*}{ Species } & \multicolumn{3}{|c|}{ Clifton } & \multicolumn{3}{|c|}{ Neal Point } & \multicolumn{3}{|c|}{ West Mud } \\
\hline & Apr & & Oct & Apr & & Oct & Apr & & Oct \\
\hline \multicolumn{10}{|l|}{ Xyalidae } \\
\hline Unidentified A & 4 & (4) & 2 & - & & - & - & & - \\
\hline Unidentified B & - & & - & - & & - & 3 & (1) & - \\
\hline Unidentified C & - & & - & - & & - & - & & 1 \\
\hline Unidentified D & - & & - & - & & - & - & & 1 \\
\hline \multicolumn{10}{|l|}{ Sphaerolaimidae } \\
\hline Sphaerolaimus balticus & - & & - & - & & - & 7 & (3) & 5 \\
\hline Sphaerolaimus gracilis & 15 & (14) & 6 & - & & - & - & & - \\
\hline Sphaerolaimus hirsutus & 2 & $(2)$ & 14 & 6 & (3) & 5 & - & & - \\
\hline \multicolumn{10}{|l|}{ Linhomoeidae } \\
\hline Desmolaimus zeelandicus & 2 & (2) & 2 & - & & - & 26 & (13) & - \\
\hline Eleutherolaimus stenosoma & - & & - & 5 & (3) & 1 & - & & 1 \\
\hline Terschellingia communis & - & & - & 137 & $(70)$ & 88 & 19 & (9) & 38 \\
\hline Terschellingia longicaudata & - & & - & 344 & (176) & 138 & 266 & $(131)$ & 61 \\
\hline \multicolumn{10}{|l|}{ Axonolaimidae } \\
\hline Axonolaimus paraspinosus & 41 & (39) & 34 & 6 & (3) & 5 & 23 & (11) & 13 \\
\hline Odontophora setosa & - & & - & 1 & (1) & 1 & 19 & $(9)$ & 6 \\
\hline \multicolumn{10}{|l|}{ Diplopeltidae } \\
\hline Diplopeltis incisus & - & & - & 1 & (1) & 1 & 2 & (1) & 5 \\
\hline \multicolumn{10}{|l|}{ Unidentified } \\
\hline 1 & - & & - & 2 & (1) & - & - & & - \\
\hline 2 & - & & - & - & & - & 2 & (1) & - \\
\hline Total & 527 & $(500)$ & 500 & 977 & $(500)$ & 500 & 1015 & $(500)$ & 500 \\
\hline
\end{tabular}

Tatal numbers of copepods in 6 cores from 3 sites in the Tamar estuary. Nomenclature after Lang (1948), Perkins (1956) and Coull (1976)

\begin{tabular}{|c|c|c|c|c|c|c|}
\hline \multirow[t]{2}{*}{ Species } & \multicolumn{2}{|c|}{ Clifton } & \multicolumn{2}{|c|}{ Neal Point } & \multicolumn{2}{|c|}{ West Mud } \\
\hline & Apr & Oct & Apr & Oct & Apr & Oct \\
\hline \multicolumn{7}{|l|}{ Ectinosomidae } \\
\hline Halectinosoma gothiceps & - & - & - & - & 80 & - \\
\hline Halectinosoma curticorne & 6 & 17 & 55 & 2 & 5 & 5 \\
\hline Halectinosoma sp. & - & - & - & - & - & 8 \\
\hline Ectinosoma melaniceps & - & - & - & - & - & 1 \\
\hline \multicolumn{7}{|l|}{ Tachidiidae } \\
\hline Microarthridion littorale & 258 & 8 & 139 & - & - & - \\
\hline Microarthridion fallax & - & 27 & 134 & 109 & 52 & 22 \\
\hline Tachidius discipes & - & - & 4 & - & 5 & 34 \\
\hline \multicolumn{7}{|l|}{ Harpacticidae } \\
\hline Harpacticus flexus & - & - & - & - & - & 11 \\
\hline \multicolumn{7}{|l|}{ Thalestridae } \\
\hline Parathalestris intermedia & - & - & 1 & - & 1 & - \\
\hline \multicolumn{7}{|l|}{ Diosaccidae } \\
\hline Amphiascoides limicola & - & 8 & 63 & 27 & 18 & 42 \\
\hline Stenhelia palustris bispinosa & - & 14 & 34 & 29 & 13 & 25 \\
\hline Robertsonia celtica & - & - & - & - & 5 & 17 \\
\hline Amonardia similis & - & - & - & - & - & 1 \\
\hline \multicolumn{7}{|l|}{ Ameiridae } \\
\hline Ameira parvula & - & - & - & - & - & 1 \\
\hline Nitocra spinipes & - & 1 & - & - & - & - \\
\hline \multicolumn{7}{|l|}{ Canthocamptidae } \\
\hline Mesochra lilljeborgi & - & - & - & - & - & 3 \\
\hline
\end{tabular}


Appendix (continued)

\begin{tabular}{|c|c|c|c|c|c|c|}
\hline \multirow[t]{2}{*}{ Species } & \multicolumn{2}{|c|}{ Clifton } & \multicolumn{2}{|c|}{ Neal Point } & \multicolumn{2}{|c|}{ West Mud } \\
\hline & Apr & Oct & Apr & Oct & Apr & Oct \\
\hline \multicolumn{7}{|l|}{ Cletodidae } \\
\hline Enhydrosoma longifurcatum & 1 & 4 & 2 & 7 & 23 & 34 \\
\hline Enhydrosoma garienis & - & 2 & 4 & 9 & 11 & 18 \\
\hline Enhydrosoma bucholtzi & - & - & 1 & - & 6 & 1 \\
\hline Enhydrosoma propinquum & - & - & - & 1 & 2 & - \\
\hline Enhydrosoma sp. & - & 1 & - & - & - & - \\
\hline Nannopus palustris & 23 & 6 & - & 1 & - & - \\
\hline \multicolumn{7}{|l|}{ Laophontidae } \\
\hline Platychelipus littoralis & - & 2 & 33 & 75 & 10 & 11 \\
\hline Paronychocamptus curticaudatus & - & - & - & - & 8 & 6 \\
\hline Heterolaophonte minuta & - & - & - & - & 10 & - \\
\hline Cyclopoidea & - & 3 & - & 1 & - & - \\
\hline Total & 288 & 93 & 469 & 261 & 249 & 240 \\
\hline
\end{tabular}

\section{LITERATURE CITED}

Alexander, W. B., Southgate, B. A., Bassindale, R. (1935). Survey of the River Tees. II. The estuary - chemical and biological. Water Pollution Research Technical Paper, London 5: 1-171

Bell, S. S. (1979). Short- and long-term variations in a high marsh meiofauna community. Estuar. coast. mar. Sci. 9: 331-350

Bell, S. S., Sherman, K. M. (1980). A field investigation of meiofaunal dispersal: tidal resuspension and its implications. Mar. Ecol. Prog. Ser, 3: 245-249

Buchanan, J. B. (1971). Measurements of the physical and chemical environment. Sediments. In: Holme, N. A. McIntyre, A. D. (ed.) Methods for the study of marine benthos. IBP Handbook No 16. Blackwell, Oxford, p. $30-52$

Capstick, C. K. (1959). The distribution of free-living nematodes in relation to salinity in the middle and upper reaches of the River Blyth estuary. J. Anim. Ecol. 28: $189-210$

Carriker, M. R. (1967). Ecology of estuarine benthic invertebrates, a perspective. In: Lauff, G. H. (ed.) Estuaries American Association for the Advancement of Science, Washington D.C., p. 442-487

Caswell, H. (1976). Community structure: a neutral model analysis. Ecol. Monogr. 46: 327-354

Coull, B. C. (1973). Estuarine meiofauna: a review: trophic relationships and microbial interactions. In: Stevenson, L. H., Colwell, R. R. (ed.) Estuarine microbial ecology. University of South Carolina Press, Columbia, p. 499-511

Coull, B. C. (1976). A revised key to Stenhelia (Delavalia) (Copepoda: Harpacticoida) including a new species from South Carolina U.S.A. Zool. J. Linn. Soc. 59: 353-364

Coull, B. C., Fleeger, J. W. (1977). Long-term temporal variation and community dynamics of meiobenthic copepods. Ecology 58: 1136-1143

Ewens, W. J. (1972). The sampling theory of selectively neutral alleles. Theor. Populat. Biol 3: 87-112

Fleeger, J. W. (1980). Community structure of an estuarine meiobenthic copepod assemblage. Estuar. coast. mar. Sci. 10: $107-118$

Gerlach, S. A., Riemann, F. $(1973,1974)$. The Bremerhaven checklist of aquatic nematodes. Veröff. Inst. Meeresforsch. Bremerh. 4 (1) (Suppl.): 1-404, (2): 405-736

Hopper, B. E., Meyers, S. P. (1967). Population studies on benthic nematodes within a subtropical seagrass community. Mar. Biol. 1: 85-96

Humphreys, W. F. (1979). Production and respiration in animal populations. J. Anim. Ecol. 48: 427-453

Huston, M. (1979). A general hypothesis of species diversity. Am. Nat. 113: 81-101

Jensen, P. (1981). Species, distribution and microhabitat theory for marine mud-dwelling Comesomatidae (Nematoda) in European waters. Cah. Biol. mar. 22: 231-241

Jensen, P. (1982). Diatorn-feeding behaviour of the free-living marine nematode Chromadorita tenuis. Nematologica 28 $71-76$

Joint, I. R., Gee, J. M., Warwick, R. M. (1982). Determination of fine-scale vertical distribution of microbes and meiofauna in an intertidal sediment. Mar. Biol. 72 : $157-164$

Lang, K. (1948). Monographie der Harpacticiden. Reprinted by Otto Koellz, Koenigstein

Levinton, J. S. (1982). Marine ecology. Prentice-Hall, New Jersey

Lorenzen, S. (1981). Entwurf eines phylogenetischen Systems der freilebenden Nematoden. Veröff. Inst. Meeresforsch. Bremerh. 7 (Suppl); 1-472

May, R. M. (1975). Patterns of species abundance and diversity. In: Cody, M. L., Diamond, J. M. (ed.) Ecology and evolution of communities. Belknap, Cambridge, Mass., p. $81-120$

McIntyre, A. D. (1969). Ecology of marine meiobenthos. Biol. Rev. 44: 245-290

McIntyre, A. D., Warwick, R. M. (1984). Meiofauna techniques. In: Holme, N. A., McIntyre, A. D. (ed.) Methods for the study of marine benthos (2nd ed.). Blackwell, Oxford, p. $217-244$

Noodt, W. (1957), Zur Okologie der Harpacticoidea (Crust. Cop.) des Eulittorals der deutschen Meeresküste und der angrenzenden Brackwasser. Z. Morph. Okol. Tiere 46: $149-242$

Odum, E. P. (1971). Fundamentals of ecology (3rd ed.), W. B. Saunders, Philadelphia 
Palmer, M. A., Brandt, R. R. (1981). Tidal variation in sediment densities of marine benthic copepods. Mar. Ecol. Prog. Ser. 4: 207-212

Perkins, E. J. (1956). Microarthridion fallax, a species of harpacticoid copepod new to science from Whitstable, Kent. Ann. Mag. nat. Hist. (12) 9: 108-111

Routledge, R. D. (1980). The form of species-abundance distributions. J. theor. Biol. 82: 547-558

Sanders, H. L. (1968). Marine benthic diversity: a comparative study. Am. Nat. 102: 243-282

Simberloff, D. (1972). Properties of the rarefaction diversity measurement. Am. Nat. 106: 414-418

Strickland, J. D. H., Parsons, T. R. (1968). A practical handbook of seawater analysis. Bull. Fish. Res. Bd Can. 167 : $1-311$

Thun, W. von (1968). Autökologische Untersuchungen an freilebenden Nematoden des Brackwassers. Unpublished thesis, Christian-Albrechts-Universität, Kiel

Ugland, K. I., Gray, J. S. (1982). Lognormal distributions and the concept of community equilibrium. Oikos 39: 171-178

Uncles, R. J., Bale, A. J., Howland, R. J. M., Morris, A. W., Elliot, R. C. A. (1983). Salinity of surface water in a partially-mixed estuary, and its dispersion at low run-off. Oceanologica Acta 6: 289-296

Warwick, R. M. (1971). Nematode associations in the Exe estuary. J. mar. biol. Ass. U.K. 51: 439-454

Warwick, R. M. (1984). Species size distributions in marine benthic communities. Oecologia 61: 32-41

Warwick, R. M., Price, R. (1979). Ecological and metabolic studies on free-living nematodes from an estuarine mudflat. Estuar, coast. mar. Sci. 9: 257-271

Whittaker, R. H. (1970). Communities and ecosystems. Macmillan, New York

Wieser, W. (1953). Die Beziehung zwischen Mundhöhlengestalt, Ernährungsweise und Vorkommen bei freilebenden marinen Nematoden. Ark. Zool. (2) 4: 439-484

Wieser, W. (1960). Benthic studies in Buzzards Bay. II. The meiofauna. Limnol. Oceanogr. 5: 121-137

This paper was submitted to the editor; it was accepted for printing on March 17, 1984 